\title{
Localization of gonadotrophin-releasing hormone I, bradykinin and their receptors in the ovaries of non-mammalian vertebrates
}

\author{
Padmasana Singh, Amitabh Krishna and Rajagopala Sridaran ${ }^{1}$ \\ Department of Zoology, Banaras Hindu University, Varanasi 221005, India and ${ }^{1}$ Department of Physiology, \\ Morehouse School of Medicine, 720 Westview Dr SW, Atlanta, Georgia 30310-1495, USA \\ Correspondence should be addressed to R Sridaran; Email: rsridaran@msm.edu
}

\begin{abstract}
GnRH I and its receptors have been demonstrated in the ovaries of various vertebrates, but their physiological significance in reproductive cascade is fragmentary. Bradykinin is a potent $\mathrm{GnRH}$ stimulator in the hypothalamus. In the present study, the presence of $\mathrm{GnRH}$ I and its receptor, and bradykinin and its receptor in the ovaries of non-mammalian vertebrates were investigated to understand their physiological significance. GnRH I immunoreactivity in the ovaries of fish, frog, reptile and bird were mainly found in the oocyte of early growing follicles and granulosa cells and theca cells of previtellogenic follicles. Vitellogenic follicles showed mild GnRH immunoreactivity. GnRH I-receptor and bradykinin were localized in the same cell types of the ovaries of these vertebrates. The presence of GnRH I, GnRH I-receptor and bradykinin in the ovaries of these vertebrates was confirmed by immunoblotting. The presence of GnRH I mRNA was demonstrated in the ovary of vertebrates using RT-PCR. The ovaries of reptiles and birds showed significantly higher intensity of immunoreactivity for GnRH I-receptor as compared with the fish and amphibian. This may have a correlation with the higher yolk content in the ovary of reptile and bird. These results suggest the possibility of $\mathrm{GnRH}$ I and bradykinin as important regulators of follicular development and vitellogenesis in the vertebrate ovary.
\end{abstract}

Reproduction (2007) 133 969-981

\section{Introduction}

The hypothalamic gonadotrophin-releasing hormone $(\mathrm{GnRH})$ is the key regulator of reproductive functions in all the vertebrate species. The major function of this decapeptide is to modulate the synthesis and release of gonadotrophins from the pituitary. GnRH binds to its receptor localized on the pituitary gonadotrophs, where it is involved in the synthesis and release of gonadotrophins. The gonadotrophins in turn stimulate hormone and gamete production by the testes and ovaries. Now, it is well documented that GnRH is not exclusively synthesized in the hypothalamus. Several in vivo (Sakamoto et al. 1993, Srivastava et al. 1995, Raga et al. 1998) and in vitro studies have shown that GnRH ligands and their agonists can have various extrahypothalamic functions (Ortmann \& Diedrich 1999). A number of studies have shown that GnRH and its receptor are also expressed in some peripheral reproductive tissues including mammary gland, ovary, endometrium and placenta, suggesting that the peptide hormone may have other extrapituitary functions in addition to its role as a GnRH (Harrison et al. 2004).

The intra-ovarian production of $\mathrm{GnRH}$ has been reinforced by demonstration of ovarian compounds with GnRH-like activity (Aten et al. 1986, 1987) and ovarian GnRH gene expression (Peng et al. 1994). The presence of $\mathrm{GnRH}$-binding sites in ovarian tissues suggests that $\mathrm{GnRH}$ acts through receptor-mediated processes in the ovary (Schirman-Hildesheim et al. 2005). In the mammalian ovary, GnRH I and its type-I receptors (GnRH I-receptor) are localized in the granulosa cells (GCs; Jones \& Hsueh 1980, Reeves et al. 1982, Kang et al. 2003) and luteal cells (Clayton et al. 1979, Bauer-Dantoin \& Jameson 1995), suggesting that this peptide may have autocrine and/or paracrine regulatory function in the ovary. Importantly, unlike the pituitary, ovarian GnRH I-receptors are activated by locally produced $\mathrm{GnRH}$ I, because the half-life of this peptide is only a few minutes, and they are found in the peripheral circulation in undetectable concentrations. A myriad of functions have been attributed to $\mathrm{GnRH}$ in the mammalian ovary (for review, Leung et al. 2003), such as a role in oocyte maturation (Hillensjo \& LeMaire 1980), follicular selection and apoptosis, steroidogenesis and effects on the corpus luteum (Srivastava et al. 1995, Kang et al. 2003). The expression of $\mathrm{GnRH}$ in immature gonads suggests that the role of $\mathrm{GnRH}$ is considerably broader than that understood presently. 
The factor(s) regulating GnRH I synthesis and secretion in the ovary remains poorly understood. Bradykinin emerged as a potent $\mathrm{GnRH}$ stimulator from hypothalamic fragment and bradykinin has been shown to localize in the hypothalamic area (Shi et al. 1998, 1999). The fact that bradykinin neurons in the hypothalamus play a physiological role in the control of GnRH and luteinizing hormone $(\mathrm{LH})$ release is supported by the finding that central administration of the bradykinin $B_{2}$ receptor antagonist into the third cerebral ventricle blocked the steroid-induced LH surge in the ovariectomized adult female rat. This suggests that bradykinin acts directly on $\mathrm{GnRH}$ neurons through a mechanism involving mediation by the bradykinin $\mathrm{B}_{2}$ receptor. It has already been reported that kinin-producing activity increases during ovulation (Smith \& Perks 1983, Espey et al. 1989, Gao et al. 1992). In a study, Kihara et al. (2000) showed the presence of a component of bradykinin and bradykinin-producing system in the porcine ovarian follicle, suggesting its role in early follicular development and ovulation. It has been demonstrated that bradykinin induces ovulation in perfused rabbit ovaries (Yoshimura et al. 1988, Hellberg et al. 1991), potentiates the action of LH (Brännström \& Hellberg 1989) and a physiological role of bradykinin in the LH surge was also implicated (Shi etal. 1998). Whether bradykinin is also involved in the regulation of ovarian $\mathrm{GnRH} I$ synthesis and secretion requires investigation. Therefore, in the present study, the localization and distribution of $\mathrm{GnRH}$ I and bradykinin and their receptors were investigated in the ovary of non-mammalian vertebrates (fish, amphibia, reptiles and aves).

\section{Materials and Methods}

\section{Sample collection}

All experiments were conducted in accordance with the principals and procedures approved by the Departmental Research Committee at Banaras Hindu University, Varanasi, India. Adult females, four to six in number and belonging to different vertebrate classes, were captured in their reproductively active phase from Varanasi and adjacent areas; for example, fish, Heteropneustes fossilis (between February and September); amphibia, Rana tigrina (between June and July); reptile, Calotes versicolor (between March and September) and aves, Estrilda amandava (between August and September). Animals were killed by decapitation as soon as they were taken to the laboratory. Ovaries were dissected out. One side of the ovary from each animal was cleaned and kept either frozen at $-20{ }^{\circ} \mathrm{C}$ for immunoblot analysis or in the RNA later (Ambion, Austin, TX, USA) at $-20^{\circ} \mathrm{C}$ for RNA extraction and real-time PCR analysis respectively. The ovary from the other side was used for immunohistochemistry. Each ovary was fixed in Bouin's fluid for $24 \mathrm{~h}$, dehydrated in ethanol, cleared in xylene, embedded in paraffin wax and serially sectioned at $6 \mu \mathrm{m}$.

\section{Classification of ovarian follicles/oocytes of non- mammalian vertebrates}

The ovarian follicles/oocytes are classified into the following types based on their size, presence of vacuoles in the periphery and amount and types of yolk accumulation: a) primordial/primary follicle - oocyte small with translucent cytoplasm, GCs and theca cells not present; b) secondary previtellogenic follicle oocyte medium-sized with opaque cytoplasm and showing varying amount of peripheral vacuoles, GCs present; c) secondary vitellogenic follicle - mediumsized oocytes with opaque cytoplasm containing pigmented granules and both granulosa and theca cells present and d) tertiary fully grown follicle - large oocytes with cytoplasm containing large yolk platelets, several layers of granulosa and thecal cells (TCs) present.

\section{RNA purification}

The total RNA from the ovary was isolated using Agilent total RNA Isolation Mini kit (Product no. 5185-6000; Agilent Technologies Inc., Wilmington, DE, USA). The purity and concentration of the isolated total RNA was checked in Agilent 2100 Bioanalyzer (Functional Genomics Core Facility, Morehouse School of Medicine, Atlanta, GA, USA).

\section{$R T$ reaction}

The total RNA from each ovarian sample $(2 \mu \mathrm{g})$ was converted to CDNA by RT reaction using RT Taqman Kit (Part no: 808-0234; Applied Biosystem Inc., Foster City, CA, USA). Hypothalamic RNA sample was used as control and reverse transcribed along with the ovarian RNA. The reaction protocol was followed according to the manufacturer's instructions. The reaction mixture contained $1 \times \mathrm{RT}$ buffer, $5.5 \mathrm{mM} \mathrm{MgCl} 2,500 \mu \mathrm{M} / \mathrm{dNTP}$, $2.5 \mu \mathrm{M}$ random hexamer, $0.4 \mathrm{U} / \mu \mathrm{l}$ RNase inhibitor and $3.125 \mathrm{U} / \mu \mathrm{l}$ MultiScribe Reverse Transcriptase in final volume of $100 \mu \mathrm{l}$. RT reactions were carried out in a DNA Thermal cycler using a program with the following reaction condition: activation of enzyme at $25{ }^{\circ} \mathrm{C}$ for $10 \mathrm{~min}, \mathrm{cDNA}$ formation at $48^{\circ} \mathrm{C}$ for $37 \mathrm{~min}$ and finally incubation at $95^{\circ} \mathrm{C}$ for $5 \mathrm{~min}$ to inactivate the enzyme and denature RNA-DNA hybrid. The quality of ssDNA and RNA was checked spectrophotometrically by taking absorbance at 260 and $280 \mathrm{~nm}$.

\section{Relative real-time PCR}

Sequence of GnRH I mRNA (rat and human) were obtained from the GenBank database of the National Center for Biotechnology Information of $\mathrm{NIH}$, USA (http://www.ncbi.nlm.nih.gov/Genbank/index.html). Using OligoPerfect Designer software (Invitrogen) primer and probe sequences were selected to optimally 
Table 1 Details of primers used in the RT-PCR.

\begin{tabular}{lllcc}
\hline Gene & Reference & \multicolumn{1}{c}{ Primers sequence $\left(5^{\prime}\right.$ to $\left.3^{\prime}\right)$} & Length of primer & Annealing temperature \\
\hline GnRHI & Rat GnRH I mRNA & L: AGGAGGATC AAATGGCAGAACC & 22 & 62.67 \\
& Accession & R: TCTTCAATCAGACGTTCCAGAGC & 23 & 62.77 \\
GnRHI & Human GnRH I, mRNA & L: CTA CTG ACT TCG TGC GTG GA & 20 & 45 \\
& Accession NM 000825.2 & R: CTG CCA GTT GAC CAA CCT CT & 20 & 19 \\
GnRHI & Rat GnRH I R mRNA & L: CTAACAATGCGTCTCTTGA & 20 & 55 \\
Receptor & Accession & R: TCCAGATAAGGTTAGAGTCG & 20 & 52.28 \\
GnRHI & Human GnRH I R mRNA & L: TTG CCT TTT TAA ACC CAT GC & 20 & 53 \\
Receptor & Accession & R: AAC ATG CTC CAA CAT TTG TG & 20 & 53 \\
$18 S$ rRNA & Rat 18 S rRNA & L: AAT TCC GAT AAC GAA CGA GA & 20 & 56.3 \\
& & R: ATC TAA GGG CAT CAC AGA CC & 60.4 \\
\hline
\end{tabular}

hybridize and amplify target cDNA sequence for realtime PCR assay. To avoid amplification of contamination of genomic DNA, primers specific for both $\mathrm{GnRH}$ I and $18 \mathrm{~S}$ (housekeeping gene) were designed for crossexon/intron boundaries. The primer sequences of GnRH I and $18 \mathrm{~S}$ are described in Table 1.

The real-time PCR assay was performed in an iCycler iQ Real time PCR detection system (Bio-Rad Laboratories) using cDNA (750 or $1125 \mathrm{ng}$ ) for each reaction. Each gene expression was assessed in a separate PCR and each reaction mixture consisted of $2 \mu \mathrm{l}$ left and right primers $(0.35 \mathrm{nM} / \mu \mathrm{l}$ concentration) of $\mathrm{GnRH} \mathrm{I}$ and $18 \mathrm{~S}$ respectively, $10 \mu$ lof $2 \times$ quantiTech SYBERGreen PCR buffer, dNTP mix including dUTP, fluorescent dyes like SYBERGreen 1 and ROX and $5 \mathrm{mM} \mathrm{MgCl} 2$ procured from Qiagen and DNase-RNase-free water to make a total volume of $20 \mu \mathrm{l}$. Samples were amplified with a precycling hold of $95^{\circ} \mathrm{C}$ for $15 \mathrm{~min}$ followed by 50 cycles of denaturation at $94{ }^{\circ} \mathrm{C}$ for $15 \mathrm{~s}$, annealing at $54{ }^{\circ} \mathrm{C}$ for $30 \mathrm{~s}$ and extension at $72{ }^{\circ} \mathrm{C}$ for $30 \mathrm{~s}$. The reaction was terminated at $72{ }^{\circ} \mathrm{C}$ for $5 \mathrm{~min}$ and cooled to $4{ }^{\circ} \mathrm{C}$. Quantification results were expressed in terms of cycle threshold value (Table 2).

\section{Antibodies}

All the antisera used in this study were obtained from commercial sources (Table 3). GnRH I antibody used in this study was highly specific and showed only $6.6 \%$ cross-reactivity with lamprey $\mathrm{GnRH}$, but very minimal cross-reactivity with other GnRHs including chicken $\mathrm{GnRH}(\mathrm{GnRH}$ II) and salmon GnRH (GnRH III) based on assessments by the manufacturer using sensitive RIA applications. A highly specific GnRH I-receptor antibody used was an MAB against 1-29 amino acid epitope at the amino terminus of human $\mathrm{GnRH}$ I-receptor.

\section{Immunohistochemistry}

Ovarian sections were processed through a standard protocol of immunohistochemistry (Table 3). After deparaffinization and rehydration, endogenous peroxidase was quenched with $0.3 \% \mathrm{H}_{2} \mathrm{O}_{2}$, equilibrated in $0.05 \mathrm{~mol} / \mathrm{l}$ Tris-Cl-0.15 mol/l NaCl (TBS, $\mathrm{pH} 7.3$ ). Background blocking was performed with normal horse serum. The tissue sections were incubated for $1 \mathrm{~h}$ at room temperature with rabbit polyclonal antibody against human GnRH I (GnRH I, Peninsula Lab Inc., San Carlos, CA, USA) diluted to 1:1500, GnRH I-receptor (Santacruz Biotechnology Inc., Santa Cruz, CA, USA) antibody diluted to 1:25 and bradykinin (Peninsula Lab Inc.) antibody diluted to 1:2000 and bradykinin $\mathrm{B}_{2}$ receptor (BD Transduction Laboratories, San Jose, CA, USA) antibody diluted to 1:25 in TBS. The detection system used was $A B C$ staining kit from Vector Laboratories, Novo Castra (UK). The peroxidase activity was revealed in $0.03 \% 3,3^{\prime}$-diaminobenzidine tetradihydrochloride (DAB; Sigma) in 0.01 M Tris- $\mathrm{Cl}$ ( $\mathrm{pH} 7.6$ ) and $0.1 \% \mathrm{H}_{2} \mathrm{O}_{2}$. Nucleus was counterstained with Elrich's hematoxylin. For preabsorbed control, the primary antibodies (in the same dilution as used for localization) were incubated with the pure antigen in the final concentration of $20 \mathrm{ng} / 100 \mu \mathrm{l}$ overnight at $4{ }^{\circ} \mathrm{C}$.

Table 2 Relative expression ratio of mRNA expression of gonadotrophin-releasing hormone $(\mathrm{GnRH})$ and GnRH I-receptor by real-time PCR in the vertebrate ovary.

\begin{tabular}{|c|c|c|c|c|c|}
\hline \multirow[b]{2}{*}{ Species } & \multirow[b]{2}{*}{ Tissue } & \multicolumn{2}{|c|}{ Rat primers } & \multicolumn{2}{|c|}{ Human primers } \\
\hline & & GnRH I & GnRH I receptor & GnRH I & GnRH I receptor \\
\hline Fish & Ovary & NA & NA & 26.91 & NA \\
\hline Amphibia & Ovary & 0.19 & NA & 20.25 & NA \\
\hline Reptile & Ovary & 5.04 & NA & 0.52 & NA \\
\hline Aves & Ovary & 0.05 & NA & NA & NA \\
\hline
\end{tabular}

The reference gene used is $18 \mathrm{~S}$ rRNA and expression compared with the control, which is hypothalamus in case of GnRH I and pituitary in the case of GnRH I-receptor. 
Table 3 Details of antibodies used for immunohistochemistry and western/slot blot.

\begin{tabular}{llllll}
\hline Antibody & \multicolumn{1}{c}{ Type } & \multicolumn{1}{c}{ Source } & $\begin{array}{c}\text { Concentration } \\
\text { used for IHC }\end{array}$ & $\begin{array}{c}\text { Concentration used } \\
\text { for western/slot blot }\end{array}$ & Control \\
\hline GnRH I & GnRH I & $\begin{array}{l}\text { Peninsula Lab Inc, San Carlos, } \\
\text { CA, USA (Cat No. IHC- 7201) }\end{array}$ & $1: 1500$ & $1: 2000$ & Preabsorbed negative control \\
GnRH I receptor & GnRH I-R & $\begin{array}{l}\text { Santa Cruz Biotechnology Inc. } \\
\text { (Cat no. SC 8028) }\end{array}$ & $1: 25$ & Negative \\
Bradykinin & Bradykinin & $\begin{array}{l}\text { Peninsula Lab Inc, San Carlos, } \\
\text { CA, USA (Cat no. IHC 7051) }\end{array}$ & $1: 2000$ & $1: 2000$ & Preabsorbed negative control \\
$\begin{array}{l}\text { Bradykinin } \\
\text { receptor }\end{array}$ & BK-R & $\begin{array}{l}\text { BD Transduction Lab, CA, USA } \\
\text { (Cat no. 610451) }\end{array}$ & $1: 25$ & Negative \\
\hline
\end{tabular}

\section{Slot blot}

Protein was extracted as described elsewhere (Chanda et al. 2004). Equal amount of protein as determined by Folin's method was equated with PBS. Ten micrograms of this sample were loaded on nitrocellulose (NC) membrane using Millipore slot blot apparatus. Nonspecific sites were blocked with $5 \%$ non-fat-dried milk in TBS, $0.02 \%$ Tween 20 . The membrane was then incubated with rabbit anti-human GnRH I antibody $(1: 2000)$ or rabbit anti-human bradykinin antibody (1:2000). Immunodetection was performed with antirabbit immunoglobulin $G$ horseradish peroxidase (IgG-HRP) conjugated (1:1000). Finally, membrane was developed with ECL. Validation of the slot blot assay was performed using serially diluted ovarian protein samples ranging between 2 and $20 \mu \mathrm{g} / \mu \mathrm{l}$. The intensity of the protein bands of the slot blot was quantified using densitometry. The graph plotted between the amounts of protein loaded and the intensity of the protein band showed strong correlation ( $r=0.98$; Fig. 1). The intraassay coefficient of variation was $<7.5 \%$ and the sensitivity of the blot was $\sim 2 \mu \mathrm{g} / \mu \mathrm{l}$.

\section{Western blot}

Protein was extracted as described elsewhere (Chanda et al. 2004). Equal amount of proteins $(300 \mu \mathrm{g})$ as

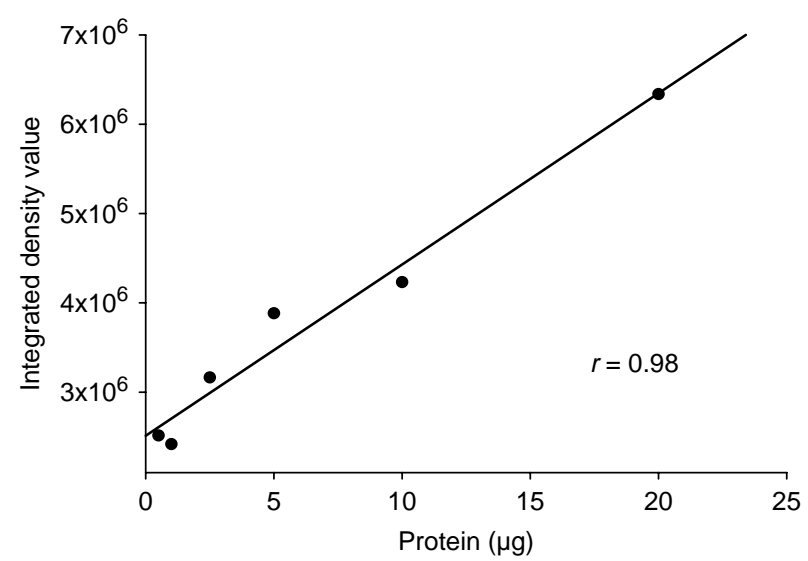

Figure 1 Validation of slot-blot assay. The amounts of protein loaded and intensity of the protein band in the slot blot showing strong correlation $(r=0.98)$. determined by Folin's method was loaded on SDS-PAGE for electrophoresis. The protein was transferred on nitrocellulose membrane (Sigma). Non-specific sites were blocked with $5 \%$ non-fat-dried milk in TBS, $0.02 \%$ Tween 20 . The membrane was then incubated with mouse anti-human GnRH I-receptor antibody $(1: 250)$ or mouse anti-human bradykinin receptor antibody (1:250). Immunodetection was performed with anti-mouse IgG-HRP conjugated $(1: 1000)$. Finally, membrane was developed with DAB. Blot was repeated thrice for each protein.

\section{Densitometry}

The densitometric analysis was performed by scanning and subsequently quantifying the blots using a computerassisted image-analysis system (AlphaEaseFC software, Alpha Innotech Corporation, San Leandro, CA, USA). The system was calibrated to have constant parameter for light (intensity and area of light beam) throughout the experiment. Absorbance was expressed as integrated density value. Each measurement was repeated twice. The data were presented as the mean of the integrity density value \pm s.E.M. of three blots of each peptide.

\section{Results}

\section{Presence of GnRH I mRNA in the ovaries of different species of non-mammalian vertebrate}

The mRNA for GnRH I has been found using primers for rat and human $\mathrm{GnRH}$ gene in the ovaries of various vertebrates and their relative $\mathrm{Ct}$ values in comparison with mammalian hypothalamus (Table 1).

\section{Distribution of GnRH I and GnRH I-receptor in the ovaries of different species of non-mammalian vertebrate}

Ovarian sections of fish, frog, reptile and bird during their reproductively active period were immunostained for GnRH I and GnRH I-receptor to demonstrate their localization and the results are summarized in Tables 4-7 and Figs 2-5. 
Table 4 Intensity and distribution of gonadotrophin-releasing hormone $(\mathrm{GnRH})$, bradykinin and their receptors immunoreactivity in the ovary of fish.

\begin{tabular}{|c|c|c|c|c|}
\hline \multirow[b]{2}{*}{ Type of follicles } & \multicolumn{4}{|c|}{ Intensity } \\
\hline & $\mathrm{GnRH}$ & GnRH receptor & Bradykinin & Bradykinin receptor \\
\hline \multicolumn{5}{|l|}{ Primary follicle } \\
\hline Oocyte & $-1+$ & $-1+$ & $-1+$ & $-1+$ \\
\hline Granulosa & * & * & * & * \\
\hline Theca & $*$ & $*$ & * & * \\
\hline \multicolumn{5}{|c|}{ Secondary previtellogenic follicle } \\
\hline Oocyte & +++ & +++ & +++ & +++ \\
\hline Granulosa & +++ & + & +++ & ++ \\
\hline Theca & ++ & + & + & + \\
\hline \multicolumn{5}{|c|}{ Secondary vitellogenic follicle } \\
\hline Oocyte & +++ & ++ & ++ & ++ \\
\hline Granulosa & + & + & + & + \\
\hline Theca & + & + & + & + \\
\hline \multicolumn{5}{|l|}{ Tertiary follicle } \\
\hline Oocyte & - & - & - & - \\
\hline Granulosa & - & - & - & - \\
\hline Theca & - & - & - & - \\
\hline Stroma & * & * & * & * \\
\hline Preabsorbed control & - & & - & \\
\hline
\end{tabular}

Scores for intensity of immunoreactivity are as follows: - , absence of immunoreactivity;,+ mild; ++ , moderate; +++ , intense; ${ }^{*}$, absence of the cells in the section.

The primordial and primary follicles generally showed no immunoreactivity in all the vertebrate species. GnRH I immunoreactivity appeared first in the oocyte of early previtellogenic secondary follicles. GnRH I immunoreactivity was much stronger in the oocytes of fish and frog than in the oocytes of reptile and bird. In ovarian follicles of bird and reptile, GnRH I immunoreactivity is localized mainly in GCs and TCs, whereas oocyte shows mild or no immunoreactivity. The intensity of GnRH I immunoreactivity increases as the follicles increase in size and immunoreactivity localized in the periphery of oocytes, GCs and TCs. The maximum intensity of $\mathrm{GnRH} I$ immunoreactivity was found in the early vitellogenic follicles. The GnRH I immunoreactivity declined to mild or no staining in the fully grown vitellogenic tertiary follicles. Atretic follicles also showed no immunoreactivity. In the ovary of reptile and bird, GnRH I immunoreactivity was also seen in the interstitial cells. The pattern of $\mathrm{GnRH}$ I-receptor immunoreactivity in the ovaries of fish, frog, reptile and bird was nearly the same as described for GnRH I. The maximum GnRH I-receptor immunoreactivity was found in the previtellogenic and vitellogenic secondary follicles. Immunoreactivity was seen in the oocytes and

Table 5 Intensity and distribution of gonadotrophin-releasing hormone $(\mathrm{GnRH})$, bradykinin and their receptors immunoreactivity in the ovary of amphibia.

\begin{tabular}{|c|c|c|c|c|}
\hline \multirow[b]{2}{*}{ Type of follicles } & \multicolumn{4}{|c|}{ Intensity } \\
\hline & $\mathrm{GnRH}$ & GnRH receptor & Bradykinin & Bradykinin receptor \\
\hline \multicolumn{5}{|l|}{ Primary follicle } \\
\hline Oocyte & + & + & + & + \\
\hline Granulosa & * & $*$ & * & * \\
\hline Theca & * & * & * & * \\
\hline \multicolumn{5}{|c|}{ Secondary previtellogenic follicle } \\
\hline Oocyte & ++ & ++ & +++ & +++ \\
\hline Granulosa & ++ & ++ & ++ & ++ \\
\hline Theca & + & + & + & + \\
\hline \multicolumn{5}{|c|}{ Secondary vitellogenic follicle } \\
\hline Oocyte & ++ & ++ & ++ & ++ \\
\hline Granulosa & ++ & + & + & + \\
\hline Theca & + & ++ & ++ & ++ \\
\hline \multicolumn{5}{|l|}{ Tertiary follicle } \\
\hline Oocyte & - & - & - & - \\
\hline Granulosa & - & - & - & - \\
\hline Theca & - & - & - & - \\
\hline Stroma & * & $*$ & * & * \\
\hline Preabsorbed control & - & & - & \\
\hline
\end{tabular}

Scores for intensity of immunoreactivity are as follows: - , absence of immunoreactivity;,+ mild; ++ , moderate;,+++ intense; ${ }^{2}$, absence of the cells in the section. 
Table 6 Intensity and distribution of gonadotrophin-releasing hormone $(\mathrm{GnRH})$, bradykinin and their receptors immunoreactivity in the ovary of reptile.

\begin{tabular}{|c|c|c|c|c|}
\hline \multirow[b]{2}{*}{ Type of follicles } & \multicolumn{4}{|c|}{ Intensity } \\
\hline & GnRH & GnRH receptor & Bradykinin & Bradykinin receptor \\
\hline \multicolumn{5}{|l|}{ Primary follicle } \\
\hline Oocyte & - & - & - & - \\
\hline Granulosa & + & + & + & + \\
\hline Theca & * & $*$ & $*$ & $*$ \\
\hline \multicolumn{5}{|c|}{ Secondary previtellogenic follicle } \\
\hline Oocyte & ++ & ++ & ++ & ++ \\
\hline Granulosa & +++ & +++ & +++ & +++ \\
\hline Theca & + & + & + & + \\
\hline \multicolumn{5}{|c|}{ Secondary vitellogenic follicle } \\
\hline Oocyte & ++ & ++ & ++ & ++ \\
\hline Granulosa & +++ & +++ & +++ & +++ \\
\hline Theca & ++ & ++ & ++ & ++ \\
\hline \multicolumn{5}{|l|}{ Tertiary follicle } \\
\hline Oocyte & + & + & + & + \\
\hline Granulosa & + & + & + & + \\
\hline Theca & + & + & + & + \\
\hline Stroma & - & - & - & - \\
\hline Preabsorbed control & - & & - & \\
\hline
\end{tabular}

Scores for intensity of immunoreactivity are as follows: - , absence of immunoreactivity; + , mild; ++ , moderate; +++ , intense; ${ }^{*}$, absence of the cells in the section.

GCs in fish and frog, whereas in the GCs and TCs in the reptile and bird follicles.

\section{Distribution of bradykinin and bradykinin $B_{2}$ receptor $(B K-R)$ in the ovaries of different species of non- mammalian vertebrates}

Ovarian sections of fish, frog, reptile and bird during their reproductively active period were immunostained for bradykinin and BK-R to demonstrate their localization and results are summarized in Tables $4-7$ and Figs 2-5.
The primordial and primary follicles generally showed no immunoreactivity for bradykinin and $B K-R$ in all the vertebrate species. Moderate to intense bradykinin immunoreactivity was noticed in the oocyte, GCs and TCs of previtellogenic and vitellogenic secondary follicles, whereas fully grown vitellogenic tertiary follicles showed mild to no immunoreactivity in the ovaries of fish, frog, reptile and bird. A strong immunoreactivity was also noticed in the interstitial cells of the reptile and bird ovaries. The pattern of BK-R immunoreactivity in the ovaries of fish, frog, reptile and bird was nearly the same as

Table 7 Intensity and distribution of gonadotrophin-releasing hormone $(\mathrm{GnRH})$, bradykinin and their receptors immunoreactivity in the ovary of bird.

\begin{tabular}{|c|c|c|c|c|}
\hline \multirow[b]{2}{*}{ Type of follicles } & \multicolumn{4}{|c|}{ Intensity } \\
\hline & $\mathrm{GnRH}$ & GnRH receptor & Bradykinin & Bradykinin receptor \\
\hline \multicolumn{5}{|l|}{ Primary follicle } \\
\hline Oocyte & - & - & - & - \\
\hline Granulosa & + & ++ & ++ & ++ \\
\hline Theca & $*$ & $*$ & $*$ & $*$ \\
\hline \multicolumn{5}{|c|}{ Secondary previtellogenic follicle } \\
\hline Oocyte & + & + & + & + \\
\hline Granulosa & +++ & +++ & +++ & +++ \\
\hline Theca & ++ & + & ++ & + \\
\hline \multicolumn{5}{|c|}{ Secondary vitellogenic follicle } \\
\hline Oocyte & - & - & - & - \\
\hline Granulosa & +++ & +++ & +++ & +++ \\
\hline Theca & ++ & ++ & ++ & ++ \\
\hline \multicolumn{5}{|l|}{ Tertiary follicle } \\
\hline Oocyte & - & - & - & - \\
\hline Granulosa & ++ & ++ & ++ & ++ \\
\hline Theca & + & + & + & + \\
\hline Stroma & - & - & - & - \\
\hline Preabsorbed control & - & & - & \\
\hline
\end{tabular}

Scores for intensity of immunoreactivity are as follows: - , absence of immunoreactivity; + , mild; ++ , moderate; +++ , intense; ${ }^{*}$, absence of the cells in the section. 


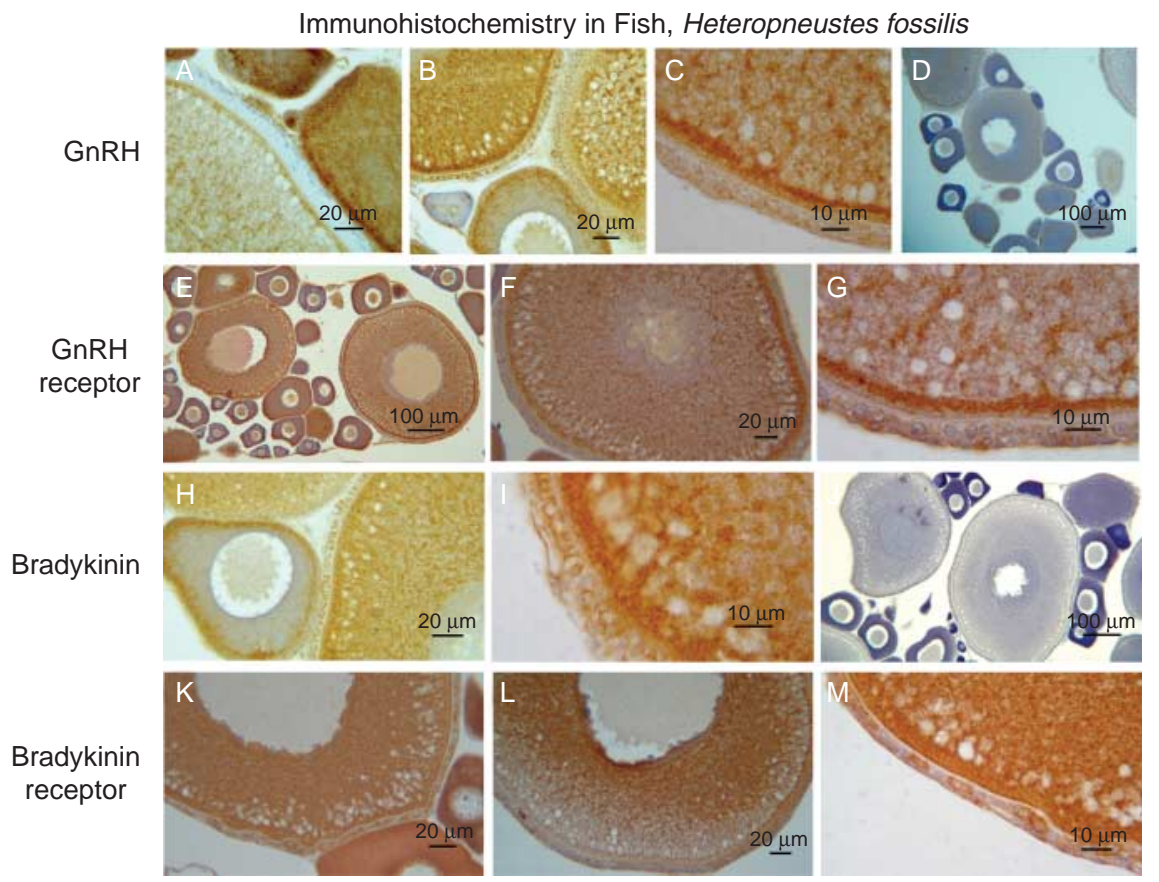

Figure 2 All figures are transverse sections of the ovary of fish, Heteropneustes fossilis. (A) Ovary showing GnRH I immunoreactivity mainly in the oocyte of growing follicles. Previtellogenic follicle shows mild GnRH I immunoreactivity throughout the cytoplasm of oocyte. Early vitellogenic follicle shows immunoreactivity in the periphery of oocyte, whereas late vitellogenic follicle shows little or no immunoreactivity. The primary follicle shows no immunoreactivity. (B) Early vitellogenic follicle enlarged to show GnRH I immunoreactivity in the periphery of oocyte. (C) Late vitellogenic follicle shows little or no immunoreactivity. (D) Preabsorbed control ovarian section showing no GnRH I immunostaining in the oocyte of secondary follicles. (E) Ovary showing GnRH I-receptor immunoreactivity in the oocyte of secondary follicles. (F) Early vitellogenic follicle showing GnRH I-receptor immunoreactivity in the periphery of oocyte. (G) Early vitellogenic follicle enlarged to show GnRH I-receptor immunoreactivity in the periphery of oocyte. $(\mathrm{H})$ Ovary showing bradykinin immunoreactivity mainly in the oocyte of growing follicles. Previtellogenic follicle shows mild bradykinin immunoreactivity throughout the cytoplasm of the oocyte. Early vitellogenic follicle shows immunoreactivity in the periphery of the oocyte, whereas late vitellogenic follicle shows little or no immunoreactivity. (I) Early vitellogenic follicle showing bradykinin immunoreactivity in the periphery of the oocyte. (J) Preabsorbed control ovarian section showing no bradykinin immunostaining in the oocyte of secondary follicles. (K) Ovary shows bradykinin receptor immunoreactivity in the oocyte of secondary follicles. (L) Early vitellogenic follicle shows bradykinin receptor immunoreactivity in the periphery of the oocyte. (M) Early vitellogenic follicle enlarged to show bradykinin receptor immunoreactivity in the periphery of the oocyte.

described for bradykinin. The maximum BK-R immunoreactivity was found in the previtellogenic and vitellogenic secondary follicles. Immunoreactivity was seen in the oocytes and GCs in fish and frog, whereas in the GCs and TCs in the reptile and bird follicles.

\section{Relative concentration of GnRH I, bradykinin and their receptors in the ovaries of different species of non- mammalian vertebrates}

GnRH I and bradykinin in the ovary and hypothalamus of fish, frog, reptile and bird were detected by slot blot. The variations in the intensity of immunostaining of the slot blots representing the concentration of $\mathrm{GnRH}$ I/bradykinin were measured by densitometry and results are shown in Figs 6 and 7. The densitometric analysis of GnRH I and bradykinin slot blots showed marked variation in the immunoreactivity between the ovaries of different vertebrate species. The ovary of the reptile showed distinctly higher intensity of GnRH I and bradykinin immunostaining when compared with the ovaries of other vertebrates. The hypothalamus of frog showed a distinctly higher intensity of GnRH I immunostaining when compared with the hypothalmus of other vertebrates.

Western blot analysis of GnRH I-receptor in the ovaries of fish, frog, reptile and bird showed a single immunoreactive band at $62 \mathrm{kDa}$. Densitometric analysis of western blot of GnRH I-receptor in the ovaries of different vertebrate species showed a marked variation. The ovaries of reptile and bird showed significantly higher intensity of immunoreactivity of GnRH I-receptor when compared with the ovaries of fish and frog as well as with the pituitary of rat.

Western blot analysis of BK-R in the ovary of fish, frog, reptile and bird showed two immunoreactive bands at 42 and $44 \mathrm{kDa}$ respectively. Densitometric analysis of western blot of BK-R in the ovaries of different vertebrate species showed a marked variation with the highest immunoreactivity found in the bird ovary. 


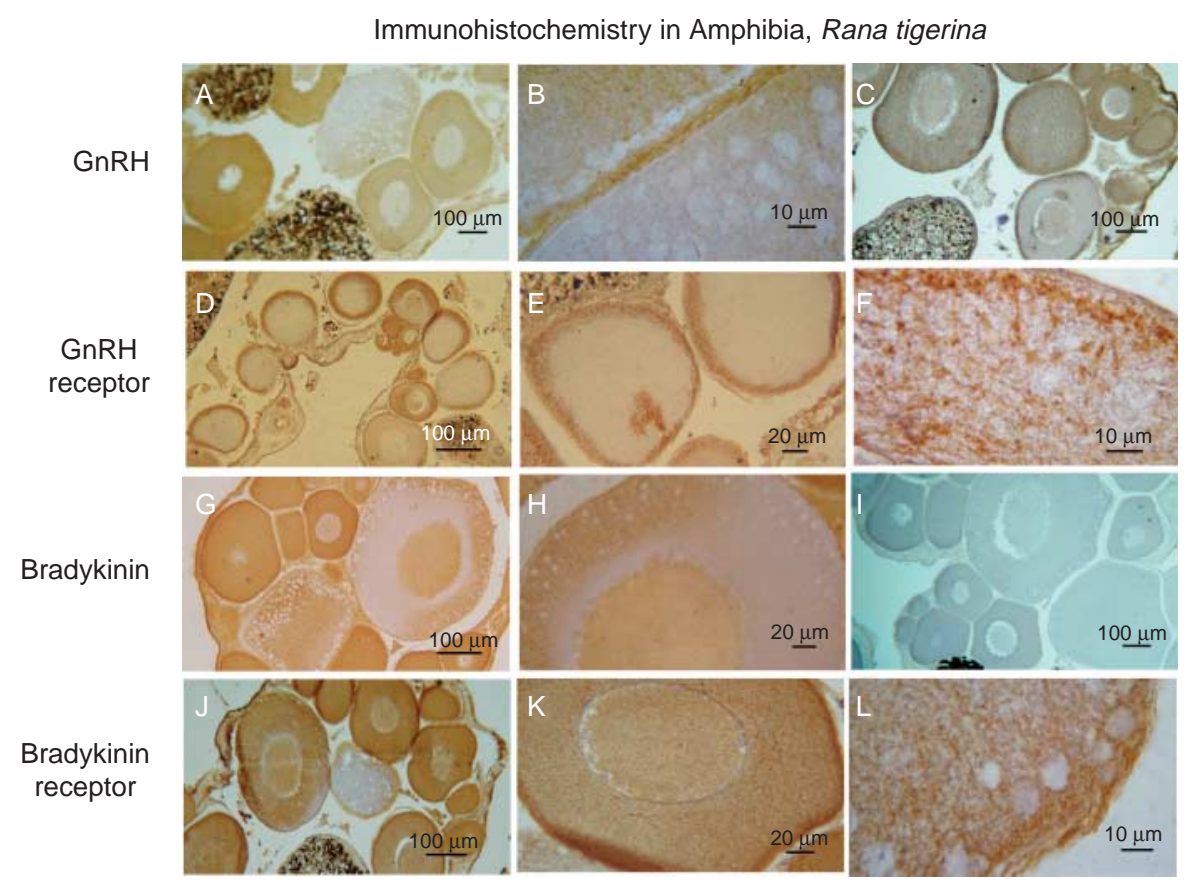

Figure 3 All figures are the transverse section of the ovary of the amphibia, Rana tigerina. (A) Ovary showing GnRH I immunoreactivity mainly in the oocyte of growing follicles. Previtellogenic follicle shows mild GnRH I immunoreactivity throughout the cytoplasm of oocyte. Late vitellogenic follicle shows little or no immunoreactivity. The primary follicle shows no immunoreactivity. (B) Early vitellogenic follicle enlarged to show GnRH I

immunoreactivity in the periphery of oocyte. (C) Preabsorbed control ovarian section showing no GnRH I immunostaining in the oocyte of secondary follicles. (D) Ovary shows GnRH I-receptor immunoreactivity in the oocyte of secondary follicles. (E) Early vitellogenic follicle shows GnRH I-receptor immunoreactivity in the periphery of oocyte. (F) Early vitellogenic follicle enlarged to show GnRH-receptor immunoreactivity in the periphery of oocyte. (G) Ovary showing bradykinin immunoreactivity mainly in the oocyte of growing follicles. Previtellogenic follicle shows mild bradykinin immunoreactivity throughout the cytoplasm of oocyte. Early vitellogenic follicle shows immunoreactivity in the periphery of oocyte, whereas late vitellogenic follicle shows little or no immunoreactivity. $(\mathrm{H})$ Early vitellogenic follicle shows bradykinin immunoreactivity in the periphery of oocyte. (I) Preabsorbed control ovarian section showing no bradykinin immunostaining in the oocyte of secondary follicles. (J) Ovary shows bradykinin receptor immunoreactivity in the oocyte of secondary follicles. (K) Early vitellogenic follicle shows bradykinin receptor immunoreactivity in the periphery of oocyte. (L) Early vitellogenic follicle enlarged to show bradykinin receptor immunoreactivity in the periphery of oocyte.

\section{Discussion}

The present immunocytochemical study demonstrates, for the first time, the distribution of GnRH I, bradykinin and their receptors in the ovaries of fish, frog, reptile and bird during the reproductively active phase. The presence of $\mathrm{GnRH}$ I was confirmed by the demonstration of its mRNA in the ovaries of fish, frog, reptile and bird using mammalian primers. The presence of GnRH I, bradykinin and their receptors was further confirmed by slot/western blot. Bradykinin has been suggested to be a potent stimulator of $\mathrm{GnRH}$ I release in the hypothalamus (Shi et al. 1998); however, whether bradykinin causes release of $\mathrm{GnRH} I$ in the ovary is not known. The presence of bradykinin together with $\mathrm{GnRH} I$ in the ovarian cell suggests the possibility of bradykinin as a regulator of $\mathrm{GnRH}$ release. The presence of complete $\mathrm{GnRH}$ I system with the ligand peptide and mRNA, and receptor and its regulator existing within the ovaries of fish to bird thus support an intra-ovarian role for $\mathrm{GnRH}$ I peptide in the vertebrate ovaries, which appears to be conserved during evolution.
$\mathrm{GnRH}$ has often been demonstrated in the ovary of several mammalian as well as non-mammalian vertebrates using RT-PCR techniques without functional assays of protein expression and localization. In nonmammalian vertebrates, GnRH I peptide has been isolated and biochemically characterized from the ovary of goldfish (Pati \& Habibi 1998, Yu et al. 1998). In the ovary of the frog, Rana esculenta, GnRH-like substance has been identified using high performance liquid chromatography followed by RIA (Battisti et al. 1994), whereas GnRH immunoreactivity using cGnRH II antiserum is observed in the ovary of newt, Triturus carnifex (Battisti et al. 1997). However, immunoreactive GnRH could not be detected in the ovary of lungfish, Protopterus annectens (King et al. 1995). In the present study, the presence of both mRNA and peptide for GnRH I are demonstrated in the ovary of vertebrate species of fish, amphibia, reptilia and birds. The presence of mRNA is shown by RT-PCR, whereas GnRH I peptide is demonstrated by immunocytochemistry (ICC) and slot blot using human GnRH I antiserum in the ovaries of 


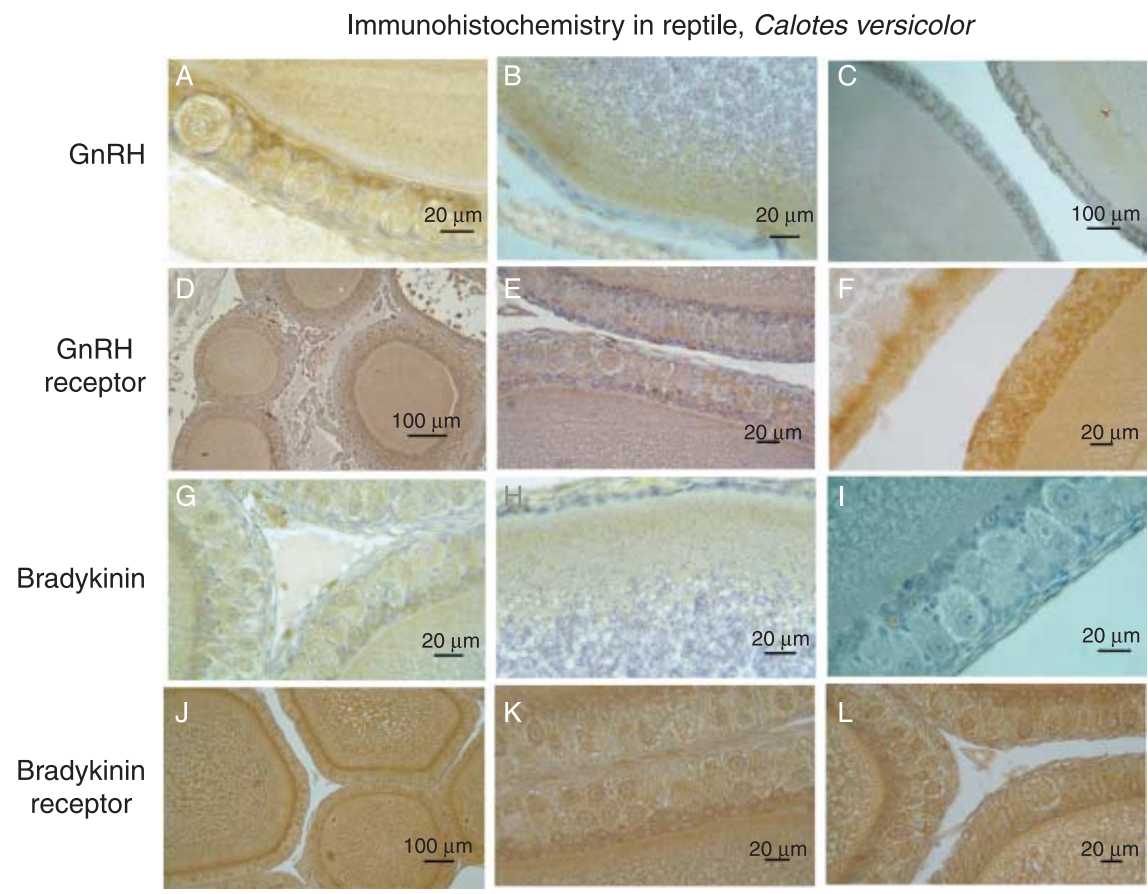

Figure 4 All figures are the transverse sections of the ovary of the reptile, Calotes versicolor. (A) Ovary showing GnRH I immunoreactivity mainly in the small granulose cell located towards the oocyte of growing follicles. (B) Early vitellogenic follicle enlarged to show GnRH I immunoreactivity in the periphery of oocyte. (C) Preabsorbed control ovarian section showing no GnRH I immunostaining in the granulosa cells as well as in the oocyte of secondary follicle. (D) Ovary shows GnRH I-receptor immunoreactivity in the oocyte of secondary follicles. (E) Early vitellogenic follicle shows $\mathrm{GnRH}$ I-receptor immunoreactivity in the small granulose cells. (F) Early vitellogenic follicle shows GnRH I-receptor immunoreactivity in the granulosa cells and late vitellogenic follicle shows GnRH I-receptor immunoreactivity in the periphery of oocyte. (G) Ovary showing bradykinin immunoreactivity mainly in the smaller granulosa cells and periphery of the oocyte of growing follicles. $(\mathrm{H})$ Early vitellogenic follicle shows bradykinin immunoreactivity in the periphery of oocyte. (I) Preabsorbed control ovarian section showing no bradykinin immunostaining in the oocyte of secondary follicles. (J) Ovary shows bradykinin receptor immunoreactivity in the granulosa cells of secondary follicles. (K) Early vitellogenic follicle shows bradykinin receptor immunoreactivity in the small granulosa cells and periphery of oocyte. (L) Early vitellonenic follicle enlarged to show bradykinin receptor immunoreactivity in the thecal cells.

vertebrate species of fish, amphibia, reptilia and bird. Within the ovary, GnRH I is localized mainly in the growing follicles. In previtellogenic follicles, mild GnRH I immunoreactivity is mainly found in the outer margin of oocytes. In the vitellogenic follicles, GnRH I immunoreactivity is observed in the GCs and TCs. The presence of GnRH I and its receptors in the GCs and TCs suggest that $\mathrm{GnRH}$ I exerts its action in an autocrine/ paracrine manner (Peng et al. 1994). GnRH is an intraovarian regulatory factor supported by localization of $\mathrm{GnRHI}$ and its receptors in the ovarian tissues as well as by previous observations on the direct effects of this decapeptide on folliculogenesis and steroidogenesis (Stojilkovic et al. 1994, Andreu et al. 1998, Kang et al. 2000, Irusta et al. 2003). The shift in immunoreactivity from oocyte to GCs and TCs as follicles grow is intriguing and needs further investigation. The present study also showed an increase in the GnRH I immunoreactivity in the GCs and TCs as the follicles grow and the absence of $\mathrm{GnRH} I$ immunoreactivity in atretic follicles. These observations suggest that $\mathrm{GnRH}$ I promotes follicular development in the vertebrate ovary. This is consistent with a recent study suggesting the proliferative role of
$\mathrm{GnRH}$ in the pituitary gonadotropes (Miles et al. 2004). The in situ studies on the rat ovary have indicated the presence of the GnRH I-receptor mRNA in the GCs of the primary, secondary and tertiary follicles (Kogo et al. 1999).

The presence of $\mathrm{GnRH}$-like peptides was first identified in luteinized rat ovaries (Aten et al. 1986), and the expression of $\mathrm{GnRH}$ has been localized to GCs of the follicle (Clayton et al. 1992). The production of $\mathrm{GnRH}$ by ovarian cell types is now well demonstrated in many vertebrate species. It has recently been shown that oocytes of the gilthead sea bream (Wong \& Zohar 2004), rat and mouse (Schirman-Hildesheim et al. 2005) produce and release gonadotrophin together with $\mathrm{GnRH}$. The available data suggest that ovarian $\mathrm{GnRH}$ receptors are located on oocytes or GCs (Uzbekova et al. 2002). A further in vitro study showed that the treatment with $\mathrm{GnRH}$ analogue enhanced, whereas the treatment with $\mathrm{GnRH}$ antagonist reduced the gonadotrophin release from the oocyte of the Gilthead Sea bream (Wong \& Zohar 2004). Collectively, these observations support the intriguing possibility that ovarian 


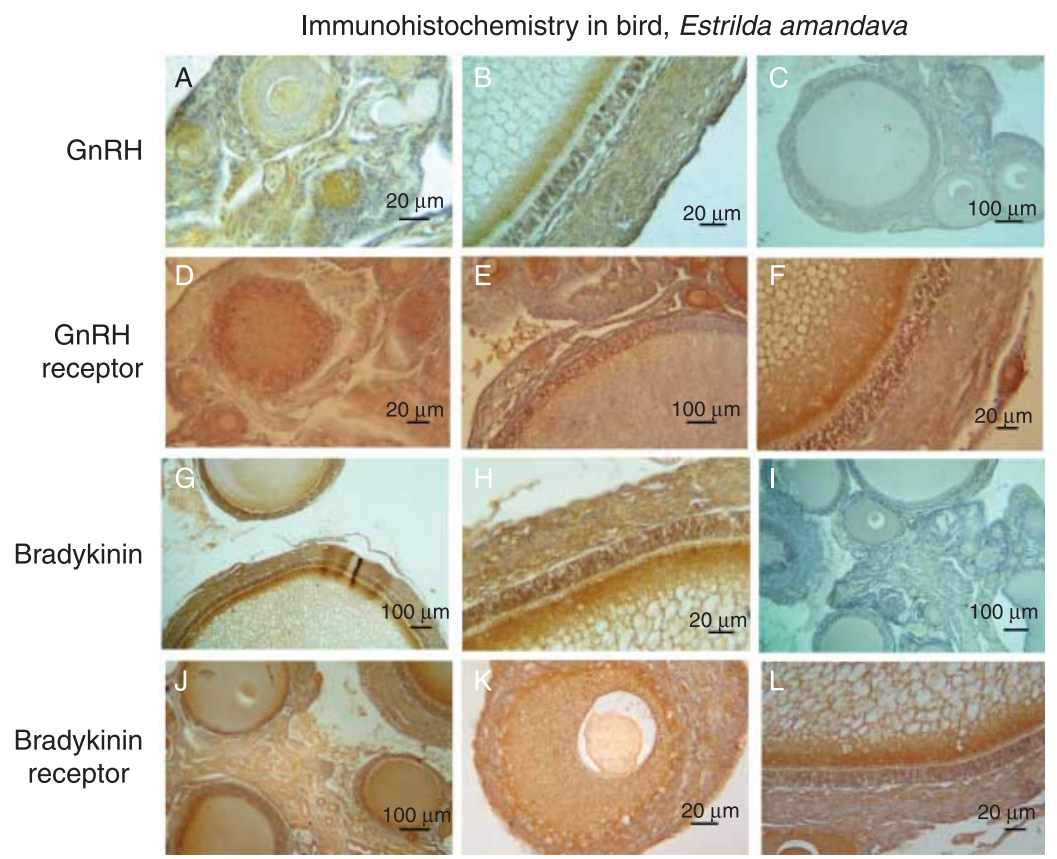

Figure 5 All figures are the transverse section of the ovary of the bird, Estrilda amandava. (A) Ovary showing GnRH I immunoreactivity mainly in the granulosa cells and the oocyte of growing follicles. (B) Late vitellogenic follicle shows GnRH I immunoreactivity in the periphery of oocyte, granulosa cells and thecal cells. (C) Preabsorbed control ovarian section showing no GnRH I immunostaining in the granulosa cells as well as in the oocyte of secondary follicle. (D) Ovary showing GnRH I-receptor immunoreactivity in the granulosa cells and oocyte of secondary follicles. (E) Early vitellogenic follicle shows GnRH I-receptor immunoreactivity in the granulosa cells and oocyte. (F) Late vitellogenic follicle showing GnRH Ireceptor immunoreactivity in the granulosa cells and periphery of oocyte. (G) Ovary showing bradykinin immunoreactivity mainly in the granulosa cells and periphery of the oocyte of growing follicles. $(\mathrm{H})$ Late vitellogenic follicle showing bradykinin immunoreactivity in the periphery of oocyte and granulosa cells. (I) Preabsorbed control ovarian section showing no bradykinin immunostaining in the oocyte and granulosa cells of secondary follicles. (J) Ovary shows bradykinin receptor immunoreactivity in the granulosa cells of secondary follicles. (K) Early vitellogenic follicle showing bradykinin receptor immunoreactivity in the granulosa cells and periphery of oocyte. (L) Late vitellogenic follicle enlarged to show bradykinin receptor immunoreactivity in the periphery of oocyte, granulose cells and thecal cells.

GnRH-gonadotrophin axis may be involved in bidirectional communication between oocytes and their companion somatic cells during follicular and/or oocyte development.

The results of this study clearly demonstrate the presence of GnRH I-receptor in the ovaries of all the vertebrate species (fish, frog, reptile and bird). Among vertebrates, the presence of GnRH I-receptor has previously been demonstrated mainly in the ovaries of several species of fishes: African catfish, Clarias gariepinus (Habibi et al. 1994), sea bream, Sparus aurata (Nabissi et al. 1997), goldfish, Carassius auratus (Pati \& Habibi 1998) and a teleost, Fugu rubripes (Moncaut et al. 2005). The presence of GnRH I-receptor in the vertebrate ovary suggests that $\mathrm{GnRH}$ I acts through a receptormediated process (Schirman-Hildesheim et al. 2005). Unlike the pituitary GnRH I-receptor, ovarian receptors are most likely activated by locally produced GnRH I, since this peptide is not found in detectable amounts in the peripheral circulation. Within the ovary, $\mathrm{GnRH}$ I-receptor immunoreactivity was mainly found in the GCs and oocytes, which are the sites of GnRH immunolocalization. This is in agreement with a study on the rat ovary, where both $\mathrm{GnRH} I$ and $\mathrm{GnRH}$
I-receptor mRNA are demonstrated to be present in the GCs of the growing follicles, suggesting the involvement of GnRH I in follicular growth and selection (Kogo et al. 1999). Similarly in mammalian testis, GnRH I is produced by the Sertoli cells, whereas GnRH I-receptor is found on the Leydig cells (Bahk et al. 1995). These observations suggest that $\mathrm{GnRH}$ receptors are closely located to the site of GnRH synthesis in the ovary as well as in other extrahypothalamic loci. These findings suggest the co-evolution of $\mathrm{GnRH}$ //GnRH I-receptor together as a coordinated functional unit. Since $\mathrm{GnRH}$ receptors are localized in multiple sites in the ovary, it can be suggested that $\mathrm{GnRH}$ receptor might be involved in the control of various ovarian functions. In addition to the direct effects of the GnRH-receptor in activating intracellular signalling, recent studies have suggested a cross-talk of GnRH-receptor with some growth factor receptors such as epidermal growth factor (EGF)-receptor (Shah et al. 2003). It is now well known that various paracrine and autocrine factors functionally interact with one another in a highly coordinated fashion (Leung et al. 2003). Thus, the actions of $\mathrm{GnRH}$ within the ovary are diverse and need further detailed investigation. 

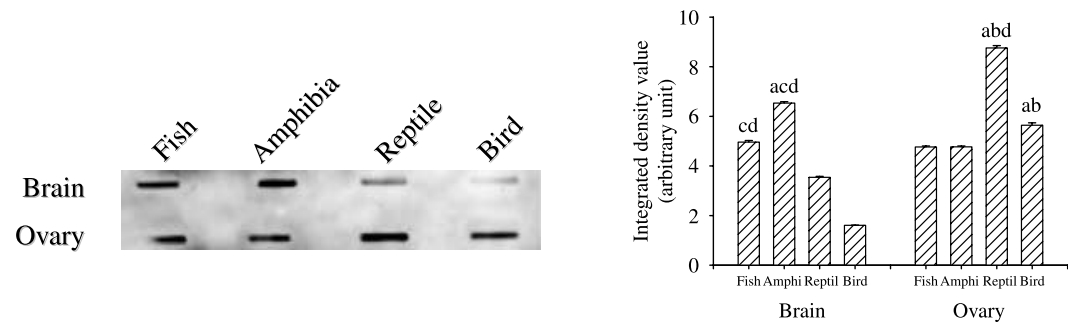

Western blot for GnRH I-R

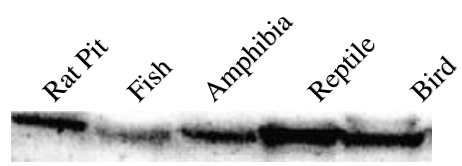

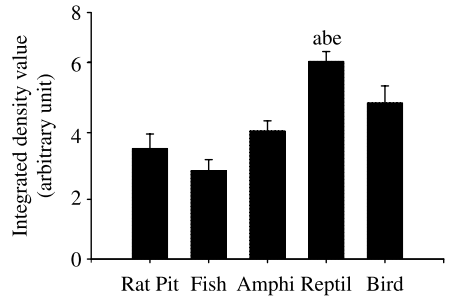

Figure 6 Slot blot for GnRH I and western blot for GnRH I-receptor. Densitometric analysis of the data showed higher $(P<0.01)$ intensity of GnRH I immunostaining in the brain of fish and amphibian as compared with reptile and bird. Intensity of $\mathrm{GnRH}$ I immunostaining in the ovary observed was significantly higher $(P<0.01)$ in reptile and bird when compared with fish and amphibian. Western blot analysis for GnRH I-R in the ovary of the reptile showed higher $(P<0.05)$ intensity of immunostaining when compared with the ovary of fish, amphibian, bird and the pituitary of rat. Values are significantly different with (a) fish, (b) amphibian, (c) reptile, (d) bird and (e) rat pituitary.
In the present study, GnRH I and GnRH I-receptor concentrations were compared in the ovaries of various vertebrate species (fish, frog, reptile and bird). The result showed relatively higher intensities of $\mathrm{GnRH}$ I and GnRH I-receptor in the ovaries of the reptile, C. versicolor, when compared with the other vertebrate species. Interestingly, the intensities of $\mathrm{GnRH}$ I-receptor in the ovary of the reptile were found significantly higher than the intensities of $\mathrm{GnRH}$ I-receptor in the rat pituitary lysate. This finding suggests that the significance of $\mathrm{GnRHI}$ in the ovary is no less than its classical role in the pituitary to stimulate the synthesis and release of gonadotrophins. The reason for the higher $\mathrm{GnRH}$
I/GnRH I-receptor concentration in the ovary of the reptile is not known, it may be correlated with the higher yolk accumulation in their ovary. The GnRH I may have other important functions in the oocyte of the reptiles, which require further detailed investigation.

Despite the fact that the roles of bradykinin in the mammalian ovary are well recognized (Kihara et al. 2000), little is known about the presence of peptide in the ovary of non-mammalian vertebrates. The present study demonstrates for the first time the presence of bradykinin as well as BK-R using immunocytochemistry and western blotting in the ovaries of different vertebrate species (fish, frog, reptile and bird). In all the vertebrate

\section{Slot Blot for Bradykinin}

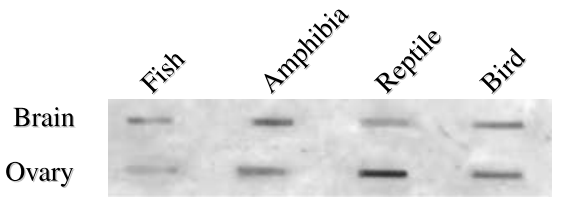

Western Blot for Bradykinin-R

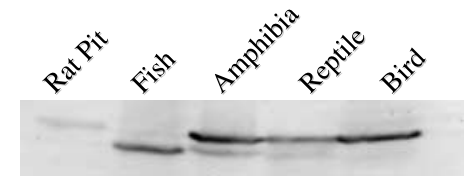

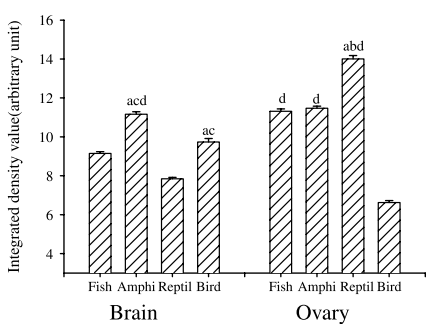

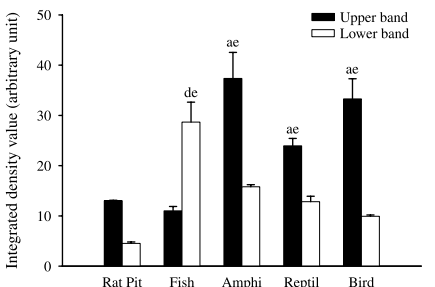

Figure 7 Slot blot for bradykinin and Western blot for bradykinin receptor. Densitometric analysis of the data showed higher $(P<0.05)$ intensity of immunostaining in the brain of amphibian and bird when compared with reptile. The ovary of the reptile showed higher $(P<0.05)$ intensity of immunostaining for bradykinin when compared with the ovary of fish, amphibian and bird. The bradykinin receptor showed two bands in the rat pituitary as well as in the ovary of all vertebrate species. The upper band predominates in amphibian, reptile and bird and showed higher $(P<0.05)$ intensity of immunostaining for bradykinin receptor when compared with fish, while the lower band showed comparatively higher $(P<0.05)$ intensity of immunostaining for bradykinin receptor in the fish when compared with the amphibian, reptile and bird. Values are significantly $(P<0.05)$ different with (a) fish, (b) amphibian, (c) reptile, (d) bird and (e) rat pituitary. 
species studied, both bradykinin and bradykinin receptors are localized in the ovarian follicles where $\mathrm{GnRHI}$ is also present. This suggests the possibility that ovarian bradykinin may be regulating $\mathrm{GnRH}$ release in the ovary as has been the case in the rat hypothalamus (Shi et al. 1998). The presence of BK-R in the ovarian cells along with GnRH I immunoreactivity further supports this possibility, although more detailed studies are needed to confirm this hypothesis.

Bradykinin may induce a number of effects in the ovary. Previous studies have demonstrated that bradykinin can induce ovulation or potentiate the effect of LH in rat ovary (Yoshimura et al. 1988, Brännström \& Hellberg 1989). Besides these, bradykinin may induce the release of prostaglandins, cause inflammatory reaction, vasodilation, etc. and may partially stimulate oocyte maturation through its effect on GnRH (Ekholm et al. 1981). Although in an earlier study the ovary of frog has failed to show any modulating effect of bradykinin on $17 \beta$-oestradiol and prostaglandin $E_{2}$ production, the presence of immunoreactivity in the ICs of the ovaries may suggest the involvement of this peptide in the steroidogenesis in this vertebrate ovary. Both bradykinin and BK-R are found to be localized mainly in the oocytes, GCs and TCs of the growing follicle. This suggests the physiological importance of bradykinin in the early stages of the follicular development as demonstrated for the mammalian ovary. Intrafollicular bradykinin-producing system is present in the porcine ovary (Kihara et al. 2000). Further, bradykinin has been noticed predominantly in the secondary follicles, which are more sensitive to the growth as well as atresia (Erickson et al. 1985). Bradykinin causes dilation of the blood vessels resulting in the increase in permeability of the secondary follicles, which in turn enhances the transfer of plasma substance into the surrounding extravascular spaces and also into the oocytes. It should, however, be noted that the enlargement of the follicles due to increased permeability is observed throughout follicular development and is particularly pronounced in the later stages.

In summary, the major findings of this study are the demonstration of both mRNA and peptide of mammalian GnRH I in the ovaries of fish, frog, reptile and bird. The ovaries of fish, frog, reptile and bird showed GnRH I immunoreactivity and showed more or less similar pattern of distribution in these vertebrates. GnRH was mainly localized in the oocyte of early growing follicles and GCs and theca cells of large maturing previtellogenic follicles. Mature vitellogenic follicles showed mild or no immunoreactivity. GnRH I-receptor, bradykinin and bradykinin receptor also showed immunoreactivity in the same cell types. The ovaries of reptiles showed relatively higher intensities of immunoreacitivity for $\mathrm{GnRH} \mathrm{I} \mathrm{and} \mathrm{GnRH} \mathrm{I-receptor} \mathrm{by} \mathrm{western} \mathrm{blot} \mathrm{as}$ compared with the ovaries of fish, amphibia and bird. Maximum GnRH I/GnRH I-receptor immunoreactivities prior to the vitellogenic phase and a transient rise in immunoreactivity were found in the previtellogenic and vitellogenic follicles, suggesting the possibility of $\mathrm{GnRH}$ $\mathrm{I}$ in the process of vitellogenesis and follicular development in the vertebrate ovary. This study further suggests the possibility of bradykinin as a regulator of ovarian GnRH I.

\section{Acknowledgements}

This study was supported by grants from NIH, USA, GM08248, HD41749, RR03034 to RS and from the University Grants Commission, New Delhi, India to AK. The authors declare that there is no conflict of interest that would prejudice the impartiality of this scientific work.

\section{References}

Andreu C, Parborell F, Vanzulli S, Chemes H \& Tesone M 1998 Regulation of follicular leutinization by a gonadotropin releasing agonist: relationship between steroidogenesis and apoptosis. Molecular Reproduction and Development 51 287-294.

Aten RF, Williams AT \& Behramn HR 1986 Ovarian gonadotropinreleasing hormone-like protein(s): demonstration and characterization. Endocrinology 118 961-967.

Aten RF, Polan ML, Bayless R \& Behrman HR 1987 A gonadotropinreleasing hormone $(\mathrm{GnRH})$-like protein in human ovaries: similarity to the GnRH-like ovarian protein of the rat. Journal of Clinical Endocrinology and Metabolism 64 1288-1293.

Bahk JY, Hyun JS, Chung SH, Lee H, Kim MO, Lee BH \& Choi WS 1995 Stage specific identification of the expression of GnRH mRNA and localization of the $\mathrm{GnRH}$ receptor in mature rat and adult human testis. Journal of Urology 154 1958-1961.

Battisti A, Vallarino M, Carnevali O, Polzonetti-Magni A \& Pierantoni R 1994 Detection and localization of gonadotrophin-releasing hormone (GnRH)-like material in the frog, Rana esculenta, ovary. Comparative Biochemistry and Physiology. Part A, Physiology 109 1097-1103.

Battisti A, Pierantoni R, Vallarino $M$, Trabucchi $M$, Carnevali $O$, Polzonetti-Magni AM \& Fasano S 1997 Detection of GnRH molecular forms in brains and gonads of the Crested Newt, Triturus carnifex - structure and signal transduction pathways. Peptides $\mathbf{1 8}$ 1029-1037.

Bauer-Dantoin AC \& Jameson JL 1995 Gonadotropin-releasing hormone receptor messenger ribonucleic acid expression in the ovary during the rat estrous cycle. Endocrinology 136 4432-4438.

Brännström M \& Hellberg P 1989 Bradykinin potentiates LH-induced follicular rupture in the rat ovary perfused in vitro. Human Reproduction 4 475-481.

Chanda D, Yonekura M \& Krishna A 2004 Pattern of ovarian protein synthesis and secretion during the reproductive cycle of Scotophilus heathi: evidence for the synthesis of albumin-like protein. Biotechnic \& Histochemistry 79 129-138.

Clayton RN, Harwood JP \& Catt KJ 1979 Gonadotropin-releasing hormone analogue binds to luteal cells and inhibits progesterone production. Nature 282 90-92.

Clayton RN, Eccleston L, Gossard F, Thalbard JC \& Morel G 1992 Rat granulosa cells express the gonadotrophin-releasing hormone gene: evidence from in situ hybridization histochemistry. Journal of Molecular Endocrinology 9 189-195.

Ekholm C, Hillensjo T \& Isaksson O 1981 Gonadotropin-releasing hormone agonists stimulate oocyte meiosis and ovulation in hypophysectomized rats. Endocrinology 108 2022-2024.

Erickson GF, Magoffin DA, Dyer CA \& Hofeditz C 1985 The ovarian androgen producing cells: a review of structure/function relationships. Endocrine Reviews 6 371-399. 
Espey LL, Tanaka N, Winn V \& Okamura HJ 1989 Increase in ovarian kallikrein activity during ovulation in the gonadotrophin-primed immature rat. Journal of Reproduction and Fertility 87 503-508.

Gao X, Greenbaum LM, Mahesh VB \& Brann DW 1992 Characterization of the kinin system in the ovary during ovulation in the rat. Biology of Reproduction 47 945-951.

Habibi HR, Pati D, Ouwens M \& Goos HJ 1994 Presence of gonadotropin-releasing hormone $(\mathrm{GnRH})$ binding sites and compounds with $\mathrm{GnRH}$ like activity in the ovary of African catfish Clarias gariepinus. Biology of Reproduction 50 643-652.

Harrison GC, Wierman ME, Nett TM \& Glode LM 2004 Gonadotropinreleasing hormone and its receptor in normal and malignant cells. Endocrine-Related Cancer 11 725-748.

Hellberg P, Larson L, Olofsson J, Hedin L \& Brännström M 1991 Stimulatory effect of bradykinin on the ovulatory process in the in vitro perfused rat ovary. Biology of Reproduction 44 269-274.

Hillensjo T \& LeMaire WJ 1980 Gonadotropin releasing hormone agonists stimulate meiotic maturation of follicle-enclosed rat oocytes in vitro. Nature 287 145-146.

Irusta G, Parborell F, Peluffo M, Manna PR, Golzalez-Calvar SI, Calandra R, Stocco DM \& Tesone M 2003 Steroidogenic acute regulatory protein in ovarian follicle of Gonadotropin-stimulated rats in regulated by a gonadotropin-releasing hormone agonist. Biology of Reproduction 68 1577-1583.

Jones JJ \& Hsueh AJ 1980 Direct inhibitory effect of gonadotrophin releasing hormone upon luteal luteinizing hormone receptors and steroidogenesis in hypophysectomized rats. Endocrinology $\mathbf{1 0 7}$ 1930-1936.

Kang SK, Choi KC, Cheng KW, Nathwani PS, Auersperg N \& Leung PKC 2000 Role of gonadotropin-releasing hormone as an autocrine growth factor in human surface epithelium. Endocrinology 141 72-80.

Kang SK, Choi KC, Yang HS \& Leung PKC 2003 Potential role of gonadotrophin-releasing hormone (GnRH)-I and $\mathrm{GnRH}-\mathrm{II}$ in the ovary and ovarian cancer. Endocrine-Related Cancer 10 169-177.

Kihara T, Kimura A, Moriyama A, Ohkubo I \& Takahashi T 2000 Identification of components of the intrafollicular bradykinin producing system in the porcine ovary. Biology of Reproduction $621160-1167$.

King JA, Millar RP, \& Pierantoni R 1995 Localization and characterization of gonadotropin-rekeasing hormones in the brain, gonads and plasma of a dipnoi (Lungfish, Pretepterus annectens). Regulatory Peptides 57 163-174.

Kogo H, Fujimoto T, Park MK \& Mori T 1999 Gonadotropin-releasing hormone receptor mRNA expression in the ovaries of neonatal and adult rats. Cells Tissues Organs 164 14-22.

Leung PKC, Cheng CK \& Zhu XM 2003 Multi-factorial role of GnRH-I and $\mathrm{GnRH}-\mathrm{II}$ in the human ovary. Molecular and Cellular Endocrinology 202 145-153.

Miles LEC, Hanyaloglu AC, Dromey JR, Pfleger KDG \& Eidne KA 2004 Gonadotropin releasing hormone receptor mediated growth supression of immortalized LBT2 gonadotrope and stable HEK293 cell lines. Endocrinology 145 194-204.

Moncaut N, Somoza G, Power DM \& Canário AVM 2005 Five gonadotrophin-releasing hormone receptors in a teleost fish: isolation, tissue distribution and phylogenetic relationships. Journal of Molecular Endocrinology 34 767-779.

Nabissi M, Pati D, Polzonetti-Magni AM \& Habibi HR 1997 Presence and activity of compounds with GnRH-like activity in the ovary of seabream Sparus aurata. American Journal of Physiology 272 $111-117$.

Ortmann O \& Diedrich K 1999 Pituitary and extrapituitary actions of gonadotrophin-releasing hormone and its analogues. Human Reproduction 14 194-206.

Pati D \& Habibi HR 1998 Presence of Salmon gonadotropin releasing hormone $(\mathrm{GnRH})$ and compounds with GnRH like activity in the ovary of goldfish. Endocrinology 139 2015-2024.
Peng C, Fan NC, Ligier M, Vaananen J \& Leung PKC 1994 Expression and regulation of gonadotropin-releasing hormone $(\mathrm{GnRH})$ and $\mathrm{GnRH}$ receptor messenger ribonucleic acids in human granulose luteal cells. Endocrinology 135 1740-1746.

Raga F, Casan EM, Kruessel JS, Wen Y, Huang HY, Nezhat C \& Polan ML 1998 Quantitative gonadotropin-releasing hormone gene expression and immunohistochemical localization in human endometrium throughout the menstrual cycle. Biology of Reproduction 59 661-669.

Reeves JJ, Tarnavsky GK \& Plant T 1982 Pituitary and ovarian luteinizing hormone releasing hormone receptors during the estrous cycle, pregnancy and lactation in rat. Biology of Reproduction $\mathbf{2 7}$ 316-319.

Sakamoto S, Tajima M, Sawaki K, Suzuki S, Kudo H, Sassa S, Kuwa K, Sugiura Y, Kasahara N \& Nagasawa H 1993 Effects of luteinizing hormone-releasing hormone analog on DNA synthesis in rat prostate and uterus. In Vivo 7 13-16.

Schirman-Hildesheim TD, Bar T, Ben-Aroya N \& Koch Y 2005 Differential gonadotropin-releasing hormone $(\mathrm{GnRH})$ and $\mathrm{GnRH}$ receptor messenger ribonucleic acid expression patterns in different tissues of the female rat across the estrous cycle. Endocrinology 146 3401-3408.

Shah BH, Soh JW \& Catt KJ 2003 Dependence of Gonadotropinreleasing hormone-induced neuronal MAPK signaling on epidermal growth factor receptor transactivation. Journal of Biological Chemistry 278 2866-2875.

Shi B, Mahesh VB, Bhatt GK, Ping L \& Brann DW 1998 Evidence for a role of bradykinin neurons in the control of gonadotropin-releasing hormone secretion. Neuroendocrinology 67 209-218.

Shi B, Bhat G, Mahesh VB, Brotto M, Nosek TM \& Brann DW 1999 Bradykinin receptor localization and cell signaling pathways used by bradykinin in the regulation of gonadotropin-releasing hormone secretion. Endocrinology 140 4669-4676.

Smith C \& Perks AM 1983 The kinin system and ovulation: changes in plasma kininogen, and in kinin-forming enzymes in the ovaries and blood of rats with 4-day estrous cycles. Canadian Journal of Physiology and Pharmacology 61 736-742.

Srivastava RK, Krishna A \& Sridaran R 1995 Follicular development, steroidogenesis and gonadotropin secretion in response to long-term treatment with a gonadotrophin-releasing hormone agonist in the rat. Journal of Endocrinology 146 349-357.

Stojilkovic SS, Reinhart J \& Catt KJ 1994 Gonadotroin-releasing hormone receptors: structure and signal transduction pathways. Endocrine Reviews 15 462-499.

Uzbekova S, Lareyre JJ, Madigou T, Davail B, Jalabert B \& Breton B 2002 Expression of prepro-GnRH and GnRH receptor messengers in rainbow trout ovary depends on the stage of ovarian follicular development. Molecular Reproduction and Development 62 47-56.

Wong TT \& Zohar Y 2004 Novel expression of gonadotropin subunit genes in oocytes of the gilthead seabream (Sparus aurata). Endocrinology 145 5210-5220.

Yoshimura Y, Espey L, Hosoi Y, Adachi T, Atlas SJ, Ghodgaonkar RB, Dubin NH \& Wallach EE 1988 The effects of bradykinin on ovulation and prostaglandin production by the perfused rabbit ovary. Endocrinology 122 2540-2546.

Yu KL, He ML, Chik CC, Lin XW, Chang JP \& Peter RE 1998 mRNA expression of gonadotropin releasing hormones and $\mathrm{GnRH}$ receptor in gold fish. General and Comparative Endocrinology 112 303-311.

Received 14 July 2006

First decision 18 August 2006

Revised manuscript received 30 January 2007

Accepted 2 February 2007 